\title{
Energy Capable Data Collection Mechanism in Wireless Sensor Networks using Mobile Collectors
}

\author{
P. Nandhini, R. Velvizhi, G. Kavitha
}

\begin{abstract}
Wireless sensor systems (WSNs) have risen as a compelling answer for an extensive variety of utilizations. The greater part of the customary WSN designs comprise of static hubs which are thickly conveyed over a detecting zone. We present another information gathering system for expansive scale remote sensor organizes by bringing portability into the system. A M-authority (portable information gatherer) begins the information gathering visit occasionally, surveys every sensor while navigating its transmission go, at that point specifically gathers information from the sensor in single-jump correspondences. We propose an information gathering calculation where different M-authorities navigate through a few shorter sub visits simultaneously to fulfill the separation/time imperatives. Recreation comes about exhibit that the proposed information gathering calculation can extraordinarily abbreviate separation of the authorities, essentially delay system entirely.
\end{abstract}

Keywords: Wireless sensor systems (WSNs), M-authority

\section{INTRODUCTION}

A Wireless sensor sort out (WSN) includes sensor focus focuses fit for get-together data from the earth and chatting with each other by techniques for remote handsets. The collected information will be passed on to at any rate one sinks, by and large by strategies for multi-skip correspondence. The sensor focus focuses are for the most part predicted that would work with batteries and are reliably passed on to not-effectively available or upsetting condition, in some cases in monster entireties. It will in general be badly arranged or difficult to dislodge the batteries of the sensor focuses. Then again, the sink is normally well off in significance. Since multi-sway directing is everything viewed as required for far away sensor focus indicates from the sinks spare significance, the inside focuses close to a sink can be stacked with emitting a lot of improvement from different focus focuses. Sensor center centers are resource obliged in term of imperativeness, processor and memory and low range correspondence and information transmission. Obliged battery control is used to work the sensor center shows and is astoundingly problematic remove or resuscitate it, when the centers kick the bowl. This will affect the system execution. Hugeness confirmation and get-together increment lifetime of the system. Advance the correspondence widen and limit the hugeness use, we have to save the vitality of sensor focus

Revised Manuscript Received on August 22, 2019.

P.Nandhini, Department of CSE,Bharath Institute of Higher Education \& Research,TamilNAdu Email: nandinisuresh@gmail.com

R. Velvizhi, Department of CSE,Bharath Institute of Higher Education \& Research,TamilNAdu Email: velvizhisp@gmail.com

G. Kavitha, Department of CSE,Bharath Institute of Higher Education \& Research,TamilNAdu Email: kavithag90@ gmail.com focuses .Sensor focuses are sent to accumulate data and required that the majority of the focuses works enterprisingly and transmit data to the degree might be conceivable. Thus, plotting controlling figurings that increase the presence time until the minute that the basic battery exclusions is a fundamental thought. Representing significance cautious figurings increment the lifetime of sensor focus focuses. In two or three uses the structure measure is more prominent required adaptable models. Significance defending in remote sensor systems has been the fundamental target, yet regardless, this oblige isn't the essential thought for skilled working of remote sensor structures. There are different objectives like adaptable arrangement, coordinating and torpidity. In a huge piece of the businesses of remote sensor structures are imagined to over saw crucial. [1],[3],[5]

\section{SINGLE-HOP DATA GATHERING}

We propose new data gathering frameworks for essential scale sensor structures when single or particular M-aces are used. In our data get-together strategy with various $\mathrm{M}$-authorities, only a particular M-gatherer needs to visit the transmission level of the data sink. While the entire framework can be secluded into sub structures .In each sub sort out, a M-star is responsible for get-together data from close sensors in the subarea. Every once in a while, the M-gatherer propels the verifiable data to one of the other close M-authorities, when two M-gatherers move acceptably close. Finally, data can be sent to the M-ace that will visit the data sink by methods of reasoning for exchanges of other M-gatherers. All data are sent to M-gatherer 1 from othr experts, and a short range later, M-gatherer 1 passes on and moves data to the data sink. [2 ],[4],[6]

\section{A. Modules: - Analyzing the information sink straightforward segments}

- Setting less jump check transmission.

- Problem in static forward focus.

- Dynamic forward focus.

- Select sensor as examining point. - Static assessing point.

- Find and amass information from contemplating focuses. 
- Handover the information o base station.

\section{B. Analyzing the data sink unpretentious components:}

Handover the data to data sink when data sink inside the transmission scope domain of sensors. The sensors which are

arranged in the extent of data sink it changes every one of the information to the data sink with least bobs.

\section{Setting less hop check transmission:}

Multi-jump organizing, bundles need to encounter various trades heretofore achieving the information sink. Obliging centrality use on the sending way does not in any way shape or form drag out system lifetime as some eminent sensors in travel. So to keep up a key decent ways from the issue in multi-avoid organizing we are setting the less bounce check transmission. [13], [15] ,[17]

- Static forward focus: When the inside point sending the information perseveringly, by then that middle point will difficulty more prominent vitality. It might causes focus dissatisfaction. [26],[28],[30]

- Dynamic forward focus point: If the forward focus is progressively changed with less skip check focus then criticalness loss of focus ought to be less.

\section{Select sensor as investigating point:}

A subset of sensors will be picked as the exploring centers, each totaling the domain data from its gathered sensors inside a particular number of exchange hops. These researching centers will shockingly save the data and move them to the versatile ace when it arrives. The investigating centers can basically be a subset of sensors in the framework or some different earth shattering devices, for instance, accumulating center concentrations with progressively conspicuous memory and more battery control. [19],[21], [20],

\section{E. Find and collect information from surveying focuse}

Since the flexible master has the flexibility to move to any domain in the recognizing field, it permits to design an ideal visit for it. Our essential thought is to discover a game-plan of exceptional focuses proposed as considering focuses in the structure and pick the voyage through the adaptable master by disregarding by each looking point in a particular movement. Precisely when the conservative master arrives, it reviews each considering point to demand information moving. Likewise, after that move the information to adaptable gatherer. [23],[22], [24]

\section{F. Handover the information to base station:}

A PP moves information packs to the helpful gatherer in a solitary skip. The versatile expert begins its visit from the static information sink, which is found either inside or outside the distinctive field, gathers information bunches at the investigating fixations and after that advantages the information to the information sink. At long last flexible master handover the information to information sink, for example, base station. [25],[27],[29]

\section{RESULTS}

In remote sensor systems are demonstrates the yield two makes 1.Nam window 2. X-diagram Finally, we have completed resource of excitements to research the measure of $\mathrm{M}$-specialists as a points of confinement among time and bundle information. This is sensible as each sub visit would interface be able to up continuously remote sensors in a solitary bob with a more noteworthy transmission range to such an extent, that it requires less sub visits to cover the whole perceiving field. [7],[9],[11]

\section{CONCLUSION}

In this paper, we proposed a reduced information get-together arrangement for wide scale sensor systems. We showed a smaller information gatherer, called a M-master, which works like an adaptable base station in the structure. A M-master begins the information get-together visit unpredictably from the static information sink, crosses the whole sensor sort out, audits sensors and assembles the information from sensors exclusively, in end returns and moves information to the information sink. In addition, it can concede the system life time fundamentally separated and the course of action that has just a static information master and plan in which the advantageous information gatherer can basically move along straight lines.

\section{REFERENCES}

1. Gowri Sankaran, B., Karthik, B. \& Vijayaragavan, S.P. 2019, "Weight ward change region plummeting change for square based image huffman coding", International Journal of Innovative Technology and Exploring Engineering, vol. 8, no. 10, pp. 4313-4316.

2. Gowri Sankaran, B., Karthik, B. \& Vijayaragavan, S.P. 2019, "Image compression utilizing wavelet transform", International Journal of Innovative Technology and Exploring Engineering, vol. 8, no. 10, pp. 4305-4308.

3. Kandavel, N. \& Kumaravel, A. 2019, "Offloading computation for efficient energy in mobile cloud computing", International Journal of Innovative Technology and Exploring Engineering, vol. 8, no. 10, pp. 4317-4320.

4. Vinoth, V.V. \& Kanniga, E. 2019, "Reversible data hiding in encrypting images-an system", International Journal of Engineering and Advanced Technology, vol. 8, no. 6, pp. 3051-3053.

5. Selvapriya, B. \& Raghu, B. 2019, "Pseudocoloring of medical images: A research", International Journal of Engineering and Advanced Technology, vol. 8, no. 6, pp. 3712-3716.

6. Senthil Kumar, K. \& Muthukumaravel, A. 2019, "Bi-objective constraint and hybrid optimizer for the test case prioritization", International Journal of Engineering and Advanced Technology, vol. 8, no. 6, pp 3436-3448.

7. Kavitha, G., Priya, N., Anuradha, C. \& Pothumani, S. 2019, "Read-write, peer-to-peer algorithms for the location-identity split", International Journal of Innovative Technology and Exploring Engineering, vol. 8 , no. 9 Special Issue 3, pp. 445-447.

8. Kaliyamurthie, K.P., Michael, G., Anuratha, C. \& Sundaraj, B. 2019, "Certain improvements in alzheimer disease classification using nove fuzzy c means clustering for image segmentation", International Journal of Innovative Technology and Exploring Engineering, vol. 8 , no. 9 Special Issue 3, pp. 599-604.

9. Kaliyamurthie, K.P., Sundarraj, B., Geo, A.V.A. \& Michael, G. 2019, "RIB: Analysis of I/O automata", International 
Journal of Innovative Technology and Exploring Engineering, vol. 8, no. 9 Special Issue 3, pp. 1019-1022.

10. Velvizhi, R., Rajabhushanam, C. \& Vidhya, S.R.S. 2019, "Opinion mining for travel route recommendation using Social Media Networks (Twitter)", International Journal of Innovative Technology and Exploring Engineering, vol. 8, no. 9 Special Issue 3, pp. 508-512.

11. Kavitha, R., Sangeetha, S. \& Varghese, A.G. 2019, "Human activity patterns in big data for healthcare applications", International Journal of Innovative Technology and Exploring Engineering, vol. 8, no. 9 Special Issue 3, pp. 1101-1103.

12. Pothumani, S., Anandam, A.K., Sharma, N. \& Franklin, S. 2019, "Extended VEOT framework - Implemented in a smart boutique", International Journal of Innovative Technology and Exploring Engineering, vol. 8, no. 9 Special Issue 3, pp. 762-767.

13. Kaliyamurthie, K.P., Michael, G., Krishnan, R.M.V. \& Sundarraj, B. 2019, "Pseudorandom techniques for the internet", International Journal of Innovative Technology and Exploring Engineering, vol. 8, no. 9 Special Issue 3, pp. 915-918.

14. Aravindasamy, R., Jeffrin Rajan, M., Rama, A. \& Kavitha, P. 2019 "Deep learning provisions in the matlab: Focus on CNN facility", International Journal of Innovative Technology and Exploring Engineering, vol. 8, no. 9 Special Issue 3, pp. 990-994.

15. Theivasigamani, S., Linda, M. \& Amudha, S. 2019, "Object sensing and its identification \& motion sensing", International Journal of Innovative Technology and Exploring Engineering, vol. 8, no. 9 Special Issue 3, pp. 545-549.

16. Mary Linda, I., Vimala, D. \& Shanmuga Priya, K. 2019, "A methodology for the emulation of IPv4", International Journal of Innovative Technology and Exploring Engineering, vol. 8, no. 9 Special Issue 3, pp. 848-852.

17. Velvizhi, R., Priya, D.J., Vimala, D. \& Linda, I.M. 2019, "Increased routing algorithm for mobile adhoc networks", International Journal of Innovative Technology and Exploring Engineering, vol. 8, no. 9 Special Issue 3, pp. 1606-1608.

18. Sangeetha, S., Anuradha, C. \& Priya, N. 2019, "DNS in real world", International Journal of Innovative Technology and Exploring Engineering, vol. 8, no. 9 Special Issue 3, pp. 937-940.

19. Geetha, C., Vimala, D. \& Priya, K.S. 2019, "Constructing multi-processors and spreadsheets with SKIVE", International Journal of Innovative Technology and Exploring Engineering, vol. 8, no. 9 Special Issue 3, pp. 516-519.

20. Yugendhar, K., Sugumar, V. \& Kavitha, P. 2019, "A novel method of univac using fuzzy logic", International Journal of Innovative Technology and Exploring Engineering, vol. 8, no. 9 Special Issue 3 , pp. 435-437.

21. Kaliyamurthie, K.P., Michael, G., Elankavi, R. \& Jijo, S.A. 2019 "Implementing aggregate-key for sharing data in cloud environmen using cryptographic encryption", International Journal of Innovative Technology and Exploring Engineering, vol. 8, no. 9 Special Issue 3, pp. 957-959.

22. Jeffrin Rajan, M., Aravindasamy, R., Kavitha, P. \& Rama, A. 2019, "A novel method of object orientation variation in $\mathrm{C}++$ and java", International Journal of Innovative Technology and Exploring Engineering, vol. 8, no. 9 Special Issue 3, pp. 708-710.

23. Nayak, R., Dinesh, S. \& Thirunavukkarasu, S. 2019, "A novel method improvement of rapid miner for the data mining applications", International Journal of Innovative Technology and Exploring Engineering, vol. 8, no. 9 Special Issue 3, pp. 457-460.

24. Sivaraman, K., Krishnan, R.M.V., Sundarraj, B. \& Sri Gowthem, S. 2019, "Network failure detection and diagnosis by analyzing syslog and SNS data: Applying big data analysis to network operations", International Journal of Innovative Technology and Exploring Engineering, vol. 8, no. 9 Special Issue 3, pp. 883-887.

25. Vimala, D., Linda, I.M. \& Priya, K.S. 2019, "Decoupling online algorithms from erasure coding in DNS", International Journal of Innovative Technology and Exploring Engineering, vol. 8, no. 9 Special Issue 3, pp. 950-953.

26. Rama, A., Kumaravel, A. \& Nalini, C. 2019, "Preprocessing medical images for classification using deep learning techniques", International Journal of Innovative Technology and Exploring Engineering, vol. 8, no. 9 Special Issue 3, pp. 711-716.

27. Sangeetha, S., Srividhya, S.R., Anita Davamani, K. \& Amudha, S. 2019, "A procedure for avoid overrun error in universal synchronous asynchronous receiver transmitter (usart) by utilizing dummy join and interrupt latency method", International Journal of Innovative Technology and Exploring Engineering, vol. 8, no. 9 Special Issue 3, pp. 657-660.
28. Aravindasamy, R., Jeyapriya, D., Sundarajan, B. \& Sangeetha, S. 2019, "Data duplication in cloud for optimal performance and security", International Journal of Innovative Technology and Exploring Engineering, vol. 8, no. 9 Special Issue 3, pp. 1156-1158.

29. Aravindasamy, R., Jeffrin Rajan, M., Sugumar, V. \& Kavitha, P. 2019 "A novel method on developing superblocks and the transistor using apodryal", International Journal of Innovative Technology and Exploring Engineering, vol. 8, no. 9 Special Issue 3, pp. 982-985.

30. Sasikumar, C.S. \& Kumaravel, A. 2019, "E-learning attributes selection through rough set theory and data mining", International Journal of Innovative Technology and Exploring Engineering, vol. 8 , no. 10 , pp. 3920-3924.

\section{AUTHORS PROFILE}

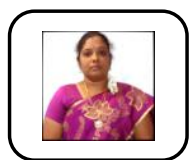

P.Nandhini,, Assistant Professor,Department of CSE,Bharath Institute of Higher Education \& Research,TamilNAdu

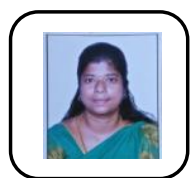

R. Velvizhi, Assistant Professor,Department of CSE,Bharath Institute of Higher Education \& Research,TamilNAdu

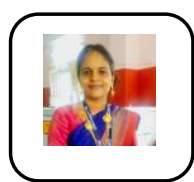

G.Kavitha Assistant Professor,Department of CSE,Bharath Institute of Higher Education \& Research,TamilNAdu 